\title{
TERRESTRIAL GASTROPODS OF THE NATURE RESERVE STARY ZAGAJ AND THE TOWN OF SKĘPE (DOBRZYŃSKIE LAKELAND). THE MALACOCOENOSIS STRUCTURE AS AN INDICATOR OF ANTHROPOGENIC INFLUENCE IN NORTH-CENTRAL POLAND
}

\author{
ElŻBIETA KuŹNiK-KowalsKa ${ }^{1 *}$, MARTA FrasunKIEWICZ ${ }^{1}$, BeATA M. POKRYSZKO²
}

\begin{abstract}
${ }^{1}$ Department of Invertebrate Systematics and Ecology, Institute of Biology, Wrocław University of Environmental and Life Sciences, Kożuchowska 5b, 51-631 Wrocław, Poland (e-mail: elzbieta.kowalska@upwr.edu.pl; frasunkiewiczmarta@gmail.com); EKK (1) https://orcid.org/0000-0002-5509-0336

${ }^{2}$ Museum of Natural History, University of Wrocław, Sienkiewicza 21, 50-335 Wrocław, Poland (e-mail: beata.pokryszko@uwr.edu.pl); 이 https://orcid.org/0000-0003-3631-3044

*corresponding author
\end{abstract}

\begin{abstract}
Thirty nine species of terrestrial gastropods were recorded from the little studied Dobrzyńskie Lakeland (north-central Poland): the nature reserve Stary Zagaj and the town of Skępe (30 from the nature reserve, 27 from the town, 18 species in common, 9 town only, 12 reserve only). The number of species per site ranged from 8 to 21 (mean 13.88), the number of specimens from 38 to 1,224 (mean 347.7). The aim of the inventory was to fill the gaps in the distribution knowledge and to identify symptoms of anthropogenic influence on the malacocoenoses. Most species were euryoecious and/or widely distributed. The results were compared to other biogeographically and ecologically similar, but mostly less humanaffected areas. The studied habitats showed unbalanced dominance structure, small between-site similarity and small proportion of forest-dwellers, combined with the near-absence or absence of clausiliids and other tree-climbing and/or timber-dependent species. These seem to be crucial symptoms of anthropogenic changes in effect at present or in the past.
\end{abstract}

KEY WORDS: gastropods, nature reserve, N-C. Poland, anthropogenic influence

\section{INTRODUCTION}

The gastropod fauna of northern Europe is a result of post-glacial colonisation from the south. Compared to the areas situated south of the boundary of Pleistocene glaciations, it is not rich, and the number of species increases from north to south (CAMERON \& POKRYSZKO 2004, 2005).

The gastropod distribution in Poland is rather well recognised and the list of species is generally complete (RIEDEL 1988, WIKTOR 2004). The only recent additions to the faunal lists are introduced species (e.g. PIEŃKOWSKA et al. 2018) whose number has increased in the last years, and records of previ- ously unrecorded native species (HORSÁK \& HÁJEK 2005, SCHENKOVÁ et al. 2012, ZAJAC et al. 2012, KSIĄŻKIEWICZ et al. 2015, POKRYSZKO et al. 2016). However, the coverage of the country is very uneven, no doubt depending on the malacological attractiveness of the various parts of Poland. For a long time it was believed that the northern malacocoenoses were species-poor. It was the potentially rich fauna from the south of the country, with its many preserved natural habitats, partly calcium-rich substratum and its varied topography, that attracted attention. Relatively modern inventories of terrestrial fauna exist for most 
regions in the south (e.g. DYDUCH 1980, PIECHOCKI 1981, POKRYSZKO \& CAMERON 2005, CAMERON et al. 2011). Only recently it has been found that, besides Białowieża Forest which is well-known for its natural character, some areas in the north hold equally rich faunas (CAMERON \& POKRYSZKO 2006, MARZEC 2010).

Some of the publications deal exclusively with faunal records (see the cycle of papers in Folia Malacologica 2006-2016), and only few are based on modern methods of assessment of diversity and structure of malacocoenoses (CAMERON \& POKRYSZKO 2004, 2006, MARZEC 2010). There are relatively recent papers on the malacocoenoses of certain vegetation formations (DZIĘCZKOWSKI 1972, CAMERON et al. 2010). Virtually all these data pertain to relatively natural forests. The north-central part of the country is still data-deficient, and constitutes a gap in the knowledge of the fauna, and especially the structure of malacocoenoses. On the other hand, this part of the country has experienced more pronounced anthropogenic changes (mainly economic exploitation and fragmentation of forests) compared to the neighbouring regions; even though some of its fragments are protected, they offer a good opportunity to study the effect of human activities on the original snail fauna. Here, we set out to compare the studied area to some geographically and environmentally close areas in order to specify the possible indicators of anthropogenic influence among the features of their malacocoenoses.

Faunistic data on the Skępe municipality are limited to the information that the common species is the Roman snail, with no information on other species (RAPORT 2018). The literature data on the malacofauna of the Kujawsko-Pomorskie Province are very scanty. Faunistic studies on the molluscs of the province were done by Drozdowski in 1950-1995. However, none of his publications (for references see RIEDEL 1988) specified which of the recorded spe-

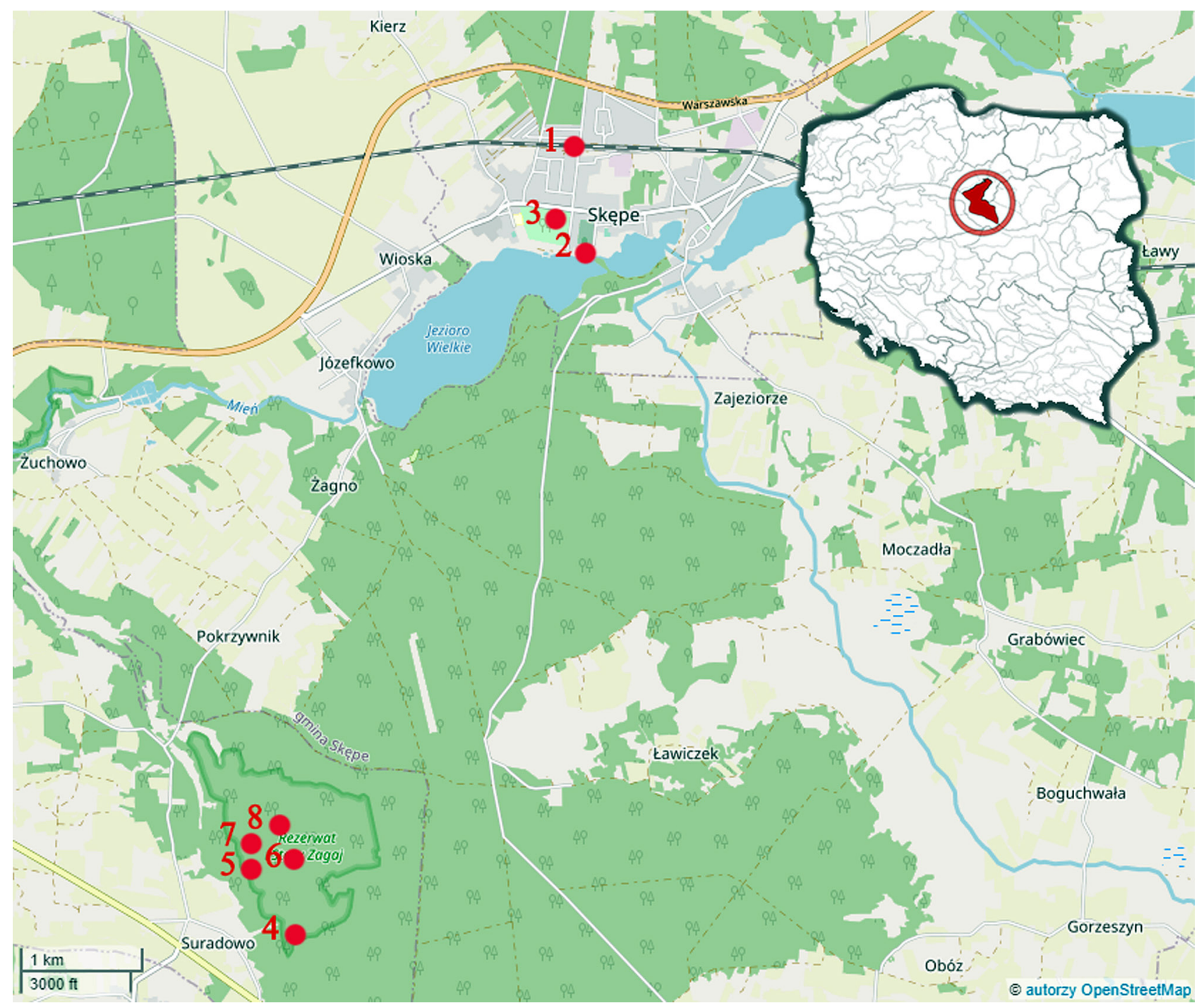

Fig. 1. Location of the study area (inset) and distribution of the sampling sites 
cies were found in the Dobrzyńskie Lakeland. In his publications (DROZDOWSKI 1980, 1997) expressed an opinion that the Kujawsko-Pomorskie Province was among the best malacologically studied parts of Poland, referring mainly to pre-war publications and his own research of 1950-1995. Actually, there are no modern inventories for the region, and it seems to be among the least studied.

\section{STUDY AREA AND SAMPLING SITES}

The Dobrzyńskie Lakeland (Dobrzyńska Upland) is a natural mesoregion situated in the southern part of the Chełmińsko-Dobrzyńskie Lakeland (Fig. 1). It is $2,800 \mathrm{~km}^{2}$ in area (KOPLIŃSKI et al. 2010). It holds glacial forms dating from the Vistulian: moraine hills and kames, parallel drumlin banks and eskers. The altitude is up to $100-150 \mathrm{~m}$ (KOPLIŃSKI et al. 2010).

The Dobrzyńskie Lakeland is agricultural, abounding in various kinds of mostly poor soils. It is much transformed anthropogenically, with few semi-natural habitats in the form of parks or mixed and coniferous forests which occupy only small areas. The lakeland has many small lakes, the largest of them (Żalskie) is 162 ha in area (KopLiŃsKI et al. 2010). Agricultural areas are extensive. The region is mostly deforested, not very densely populated, with little industry.

Field studies were done in the nature reserve Stary Zagaj and in the town of Skępe from May to October 2015. Each site was sampled in three different seasons: spring, summer, and autumn, by two persons, at least one of them an experienced collector. The location of the study area and the sampling sites are shown in Fig. 1, their numbers, characteristics and geographic coordinates in Table 1.

\section{ANTHROPOGENIC HABITATS IN THE TOWN OF SKĘPE}

The town of Skępe, located in the eastern part of the Kujawsko-Pomorskie Province, has 3,688 inhabitants (NowAK et. al. 2013). Parks and lakes are within the town's boundaries, and its environs are forest-covered. The soils in the town and its surroundings are brown, humus and rusty soils. Smaller fragments hold black, podzol and peaty soils.

Site 1. Railway embankment. The site (Fig. 2) is much human-transformed, with railway tracks bordered by stones and adjacent meadow with few shrubs. It is well insolated, mostly dry, but with patches of wet soil in places. The vegetation is mainly composed of great burdock, wormwood or tansy, and sedge and grass in the damp patches.

Site 2. Lake Wielkie (Fig. 3) in Skępe has the poorest vascular vegetation among the region's lakes;
Besides identifying the parameters of malacocoeonosis structure that would reflect anthropogenic influence, we sought to inventory the area's fauna, to fill the gap in the knowledge of the country's fauna, providing a list of the region's gastropod species, and to identify the possible refugia as well as endangered and rare species.

Table 1. Characteristics of sampling sites

\begin{tabular}{clc}
\hline Site & \multicolumn{1}{c}{ Habitat type } & \multicolumn{1}{c}{ Coordinates } \\
\hline 1 & Railway embankment & $52^{\circ} 52.32^{\prime} \mathrm{N}, 19^{\circ} 20.41^{\prime} \mathrm{E}$ \\
2 & Lake shore & $52^{\circ} 51.85^{\prime} \mathrm{N}, 19^{\circ} 20.47^{\prime} \mathrm{E}$ \\
3 & Borek Park & $52^{\circ} 51.99^{\prime} \mathrm{N}, 19^{\circ} 20.28^{\prime} \mathrm{E}$ \\
4 & Thermophilous oak forest & $52^{\circ} 48.72^{\prime} \mathrm{N}, 19^{\circ} 18.55^{\prime} \mathrm{E}$ \\
5 & Currant-alder carr & $52^{\circ} 49.02^{\prime} \mathrm{N}, 19^{\circ} 18.21^{\prime} \mathrm{E}$ \\
6 & Ash-alder riverine forest & $52^{\circ} 49.08^{\prime} \mathrm{N}, 19^{\circ} 18.51^{\prime} \mathrm{E}$ \\
7 & Subboreal mixed forest & $52^{\circ} 49.23^{\prime} \mathrm{N}, 19^{\circ} 18.41^{\prime} \mathrm{E}$ \\
8 & Subcontinental oak- & $52^{\circ} 49.15^{\prime} \mathrm{N}, 19^{\circ} 18.19^{\prime} \mathrm{E}$ \\
& \\
\hline
\end{tabular}

this pertains especially to submerged plants. Overall, the region's lakes are eutrophic, with rather lush but species-poor vascular vegetation (KĘPCZYŃSKI 1960). The lake shore trees are few, and human-transformed habitats - meadows with short grass - predominate next to the lake. The soil is very damp and the lake margin is periodically flooded.

Site 3. Borek Park. The park (Fig. 4) is ca. 10 ha in area and is a remnant of the once extensive Mazovian Forest. Trees are diverse, with predominance of native species: oak, sycamore maple, pine, spruce, Norway maple and linden. Besides, exotic shrubs and trees have been introduced, such as white horse-chestnut, blue spruce, Chinese juniper, pea-fruited cypress or red oak (KOPLIŃSKI et al. 2010).

\section{SEMI-NATURAL HABITATS - NATURE RESERVE STARY ZAGAJ}

The nature reserve is situated in the marginal, most fertile part of a large forest complex - part of the Głęboczek Forest Division, south of Skępe (central point of the reserve: $52^{\circ} 49.12^{\prime} \mathrm{N}, 19^{\circ} 18.72 ' \mathrm{E}$ ). It is located on a small stream, a tributary to the Mienia River. Its surface area is ca. 130 ha. Established in 2011, it is part of Natura 2000 network (PLH040038). Its aim is to protect deciduous forests of natural character (RĄKOWSKI et al. 2012). The substratum is outwash-sandy, with numerous marshy hollows. The soils are mostly poor, podzolic soils formed of 


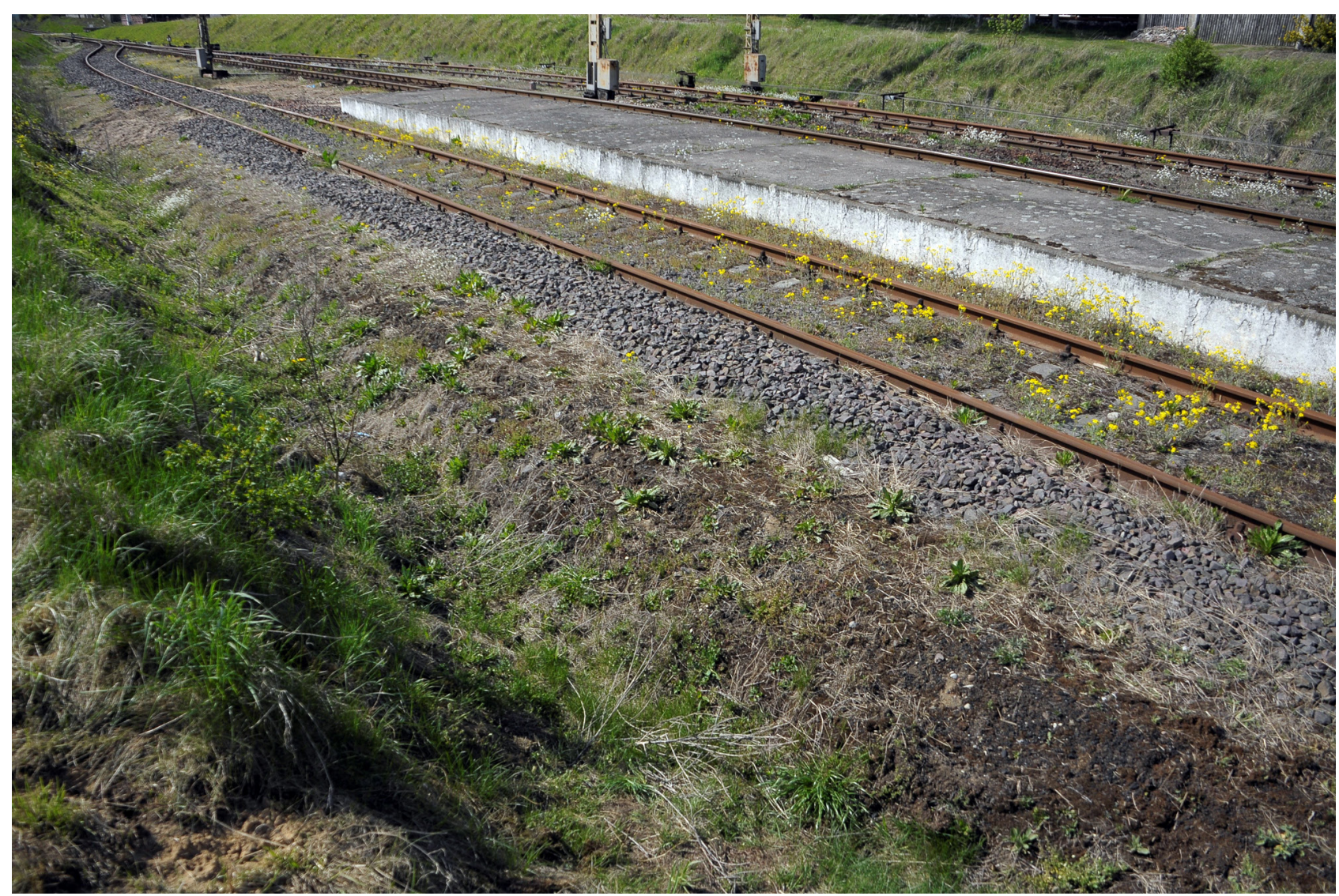

Fig 2. Site 1, railway embankment. Photo: M. FrASUNKIEWICZ

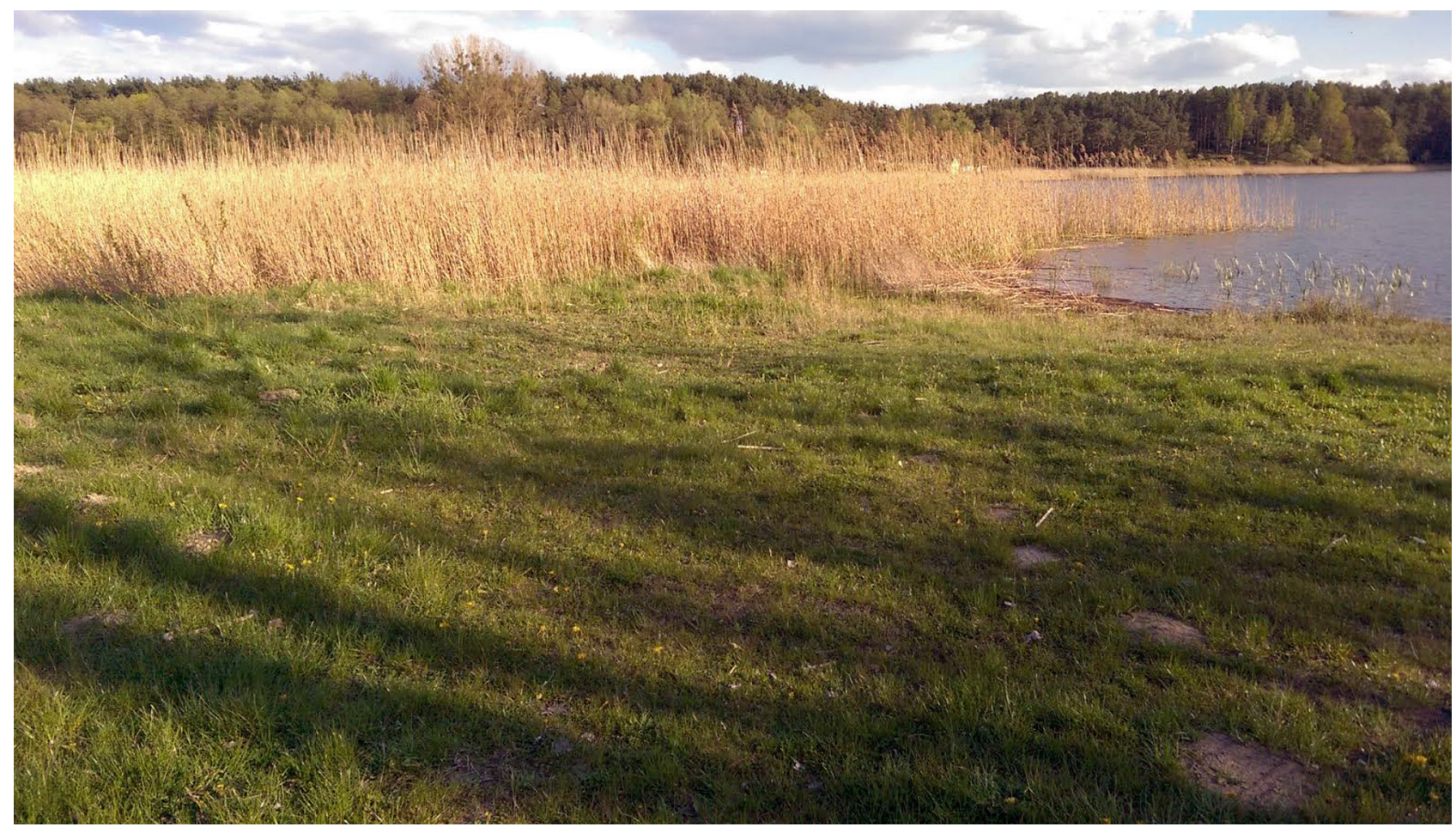

Fig. 3. Site 2, Lake Wielkie. Photo: M. FrASUNKIEWICZ 


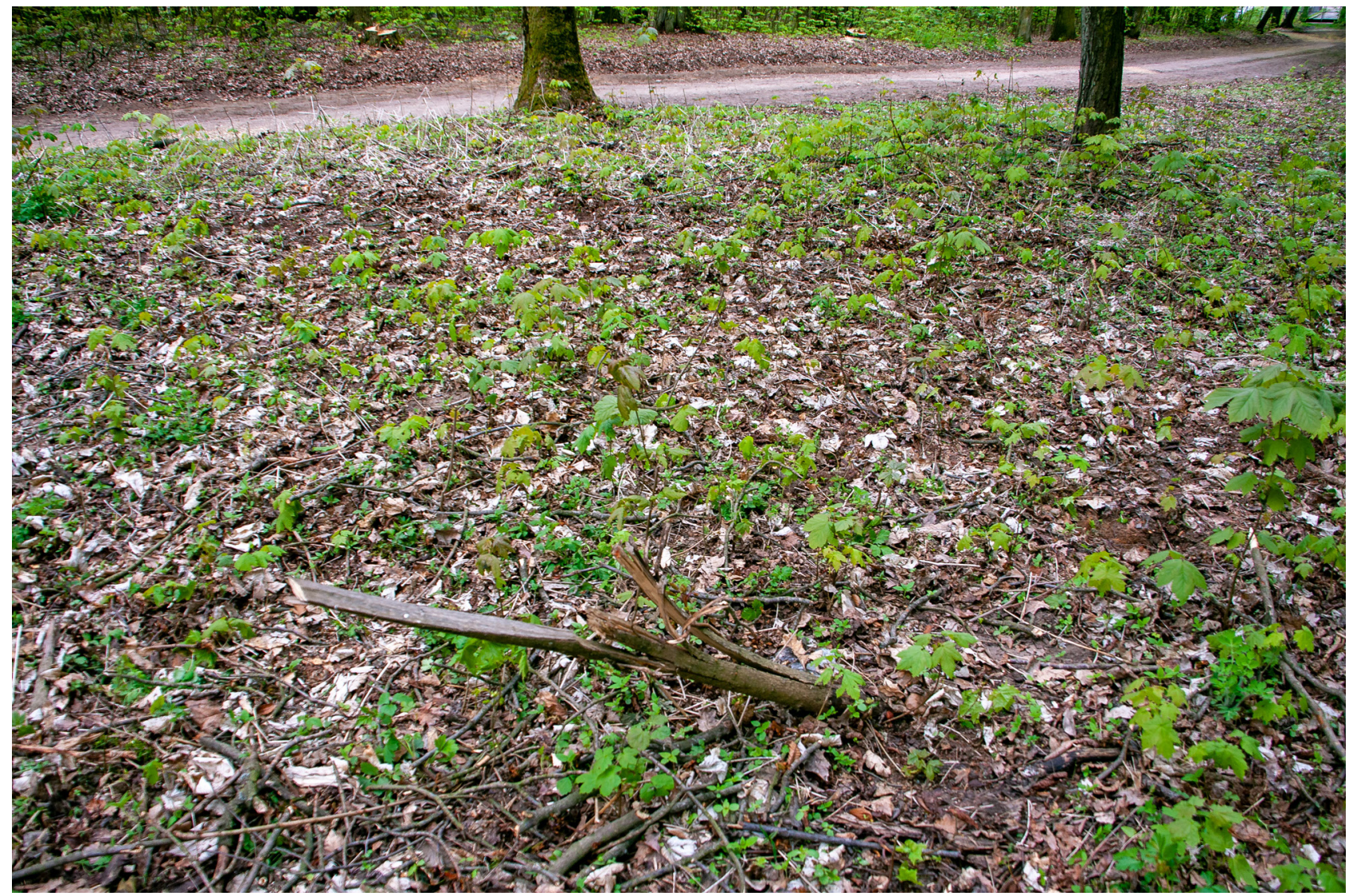

Fig. 4. Site 3, Borek Park. Photo: M. FrASUNKIEWICZ

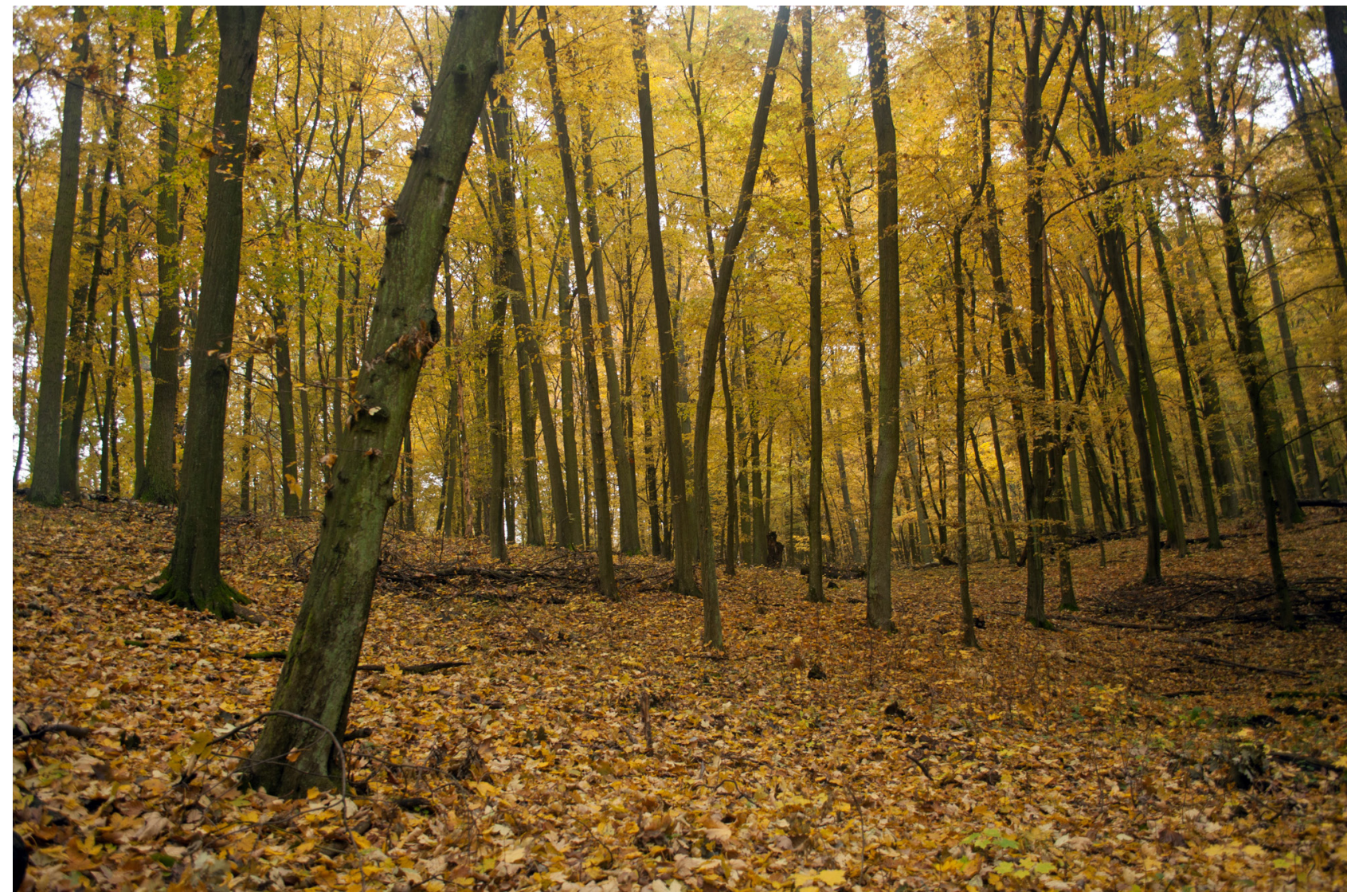

Fig. 5. Site 4, thermophilous oak forest. Photo: M. FRASUNKIEWICZ 


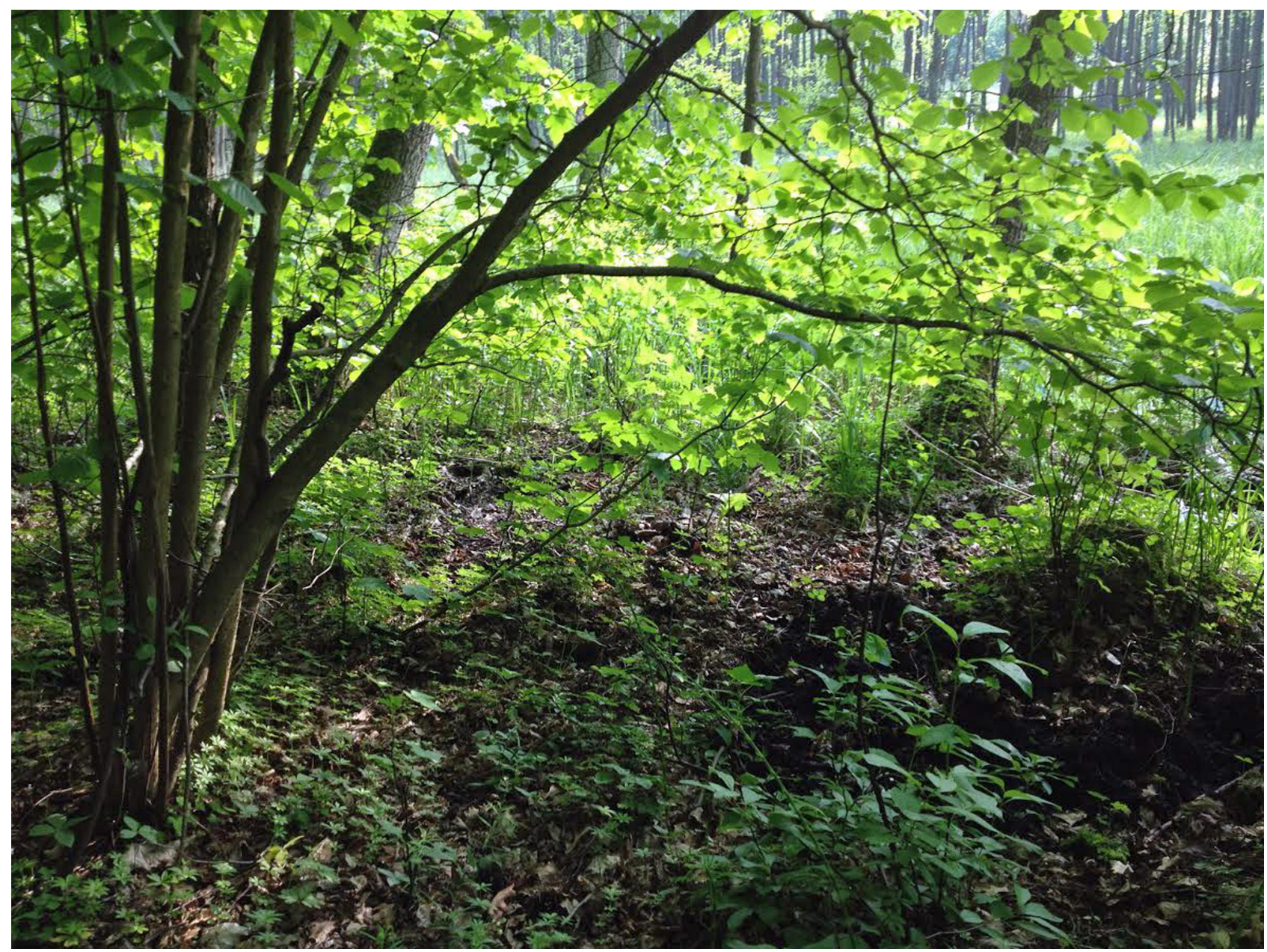

Fig. 6. Site 5, currant-alder carr. Photo: M. FRASUNKIEWICZ

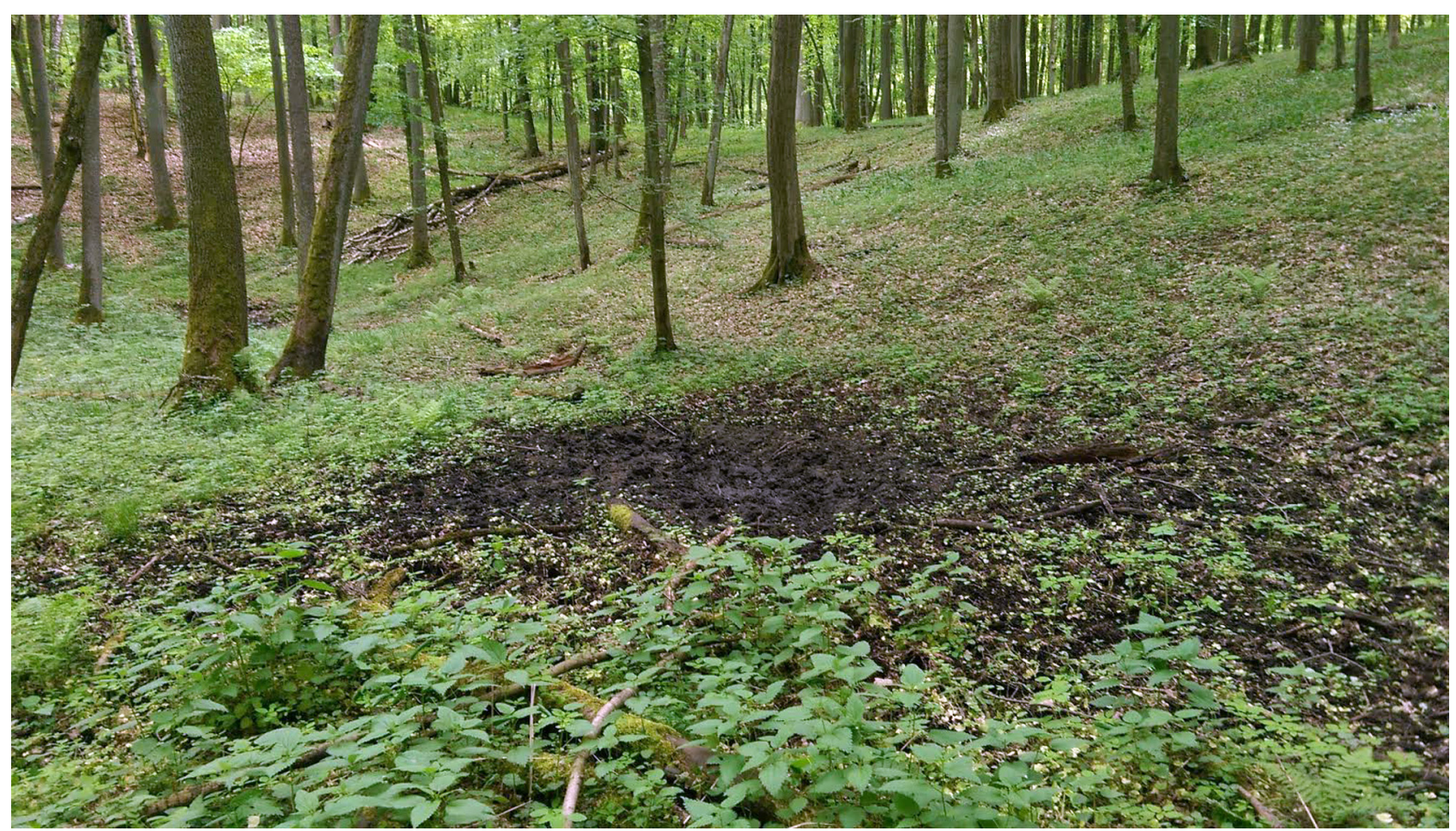

Fig. 7. Site 6, ash-alder riverine forest. Photo: M. FRASUNKIEWICZ 


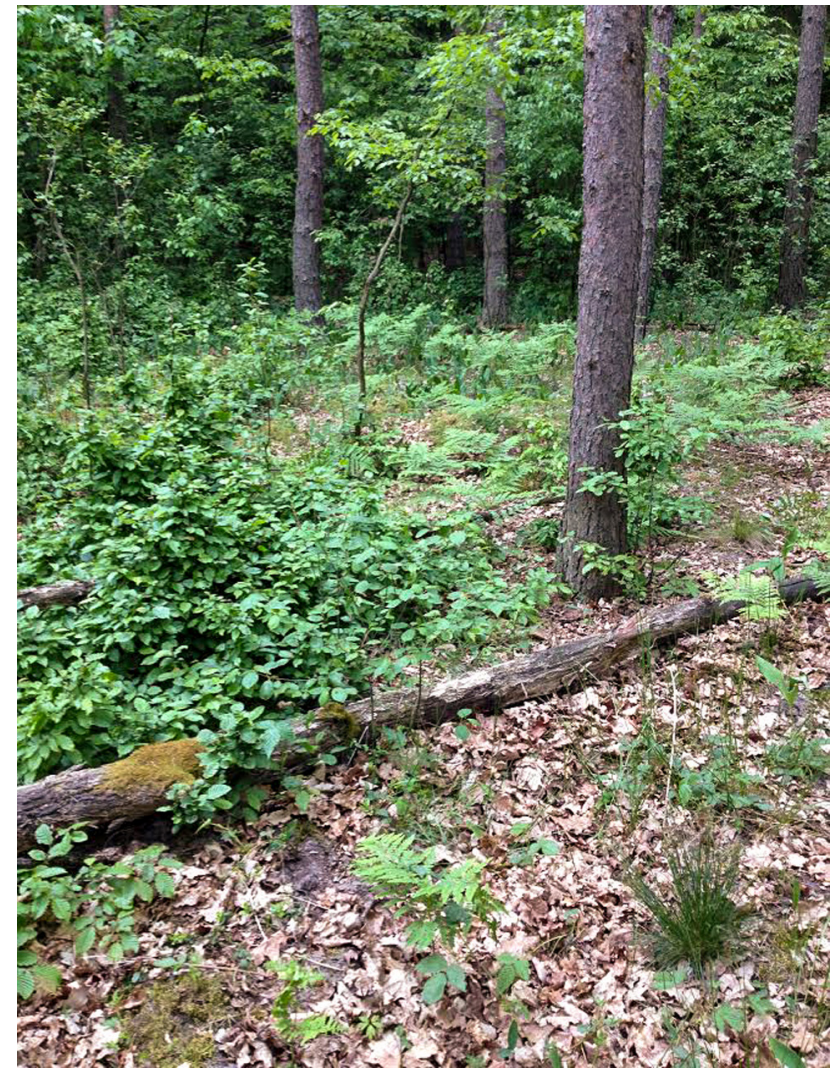

Fig. 8. Site 7, subboreal mixed forest, Sarmatian variant. Photo: M. FRASUNKIEWICZ clayey and poorly clayey sands. Brown soils occur in places. Peaty soils are present in stream valleys and hollows (KĘPCZYŃSKI \& CYZMAN 1995). Deciduous tree stands prevail in Stary Zagaj. Though oak stands predominate, the reserve holds seven forest kinds, some of them rare in the region: currant-alder carr, ash-alder riverine forest, elm-ash riverine forest, lowland form of submontane ash riverine forest, subcontinental oak-hornbeam forest, thermophilous oak forest and subboreal mixed forest, Sarmatian variety. Almost all the deciduous forest types of this part of Poland are represented. The total number of recorded vascular plant species is 476, many of them protected and/or rare, among others Dryopteris cristata, Polypodium vulgare, Euphorbia dulcis, Viola epipsila, Daphne mezereum, Hedera helix, Primula veris, Lilium martagon and Hierochlöe australis (RĄKOWSKI et al. 2005). Since 2017 it has been nominally under strict protection, but the forest is still managed to some extent and holds some plantations, for example larch. The tree stands are mostly young (see e.g. Figs 5-6). Site 4. Thermophilous oak forest (Potentillo albaeQuercetum petraeae Libb. 1933). This type of forest (Fig. 5) grows on mesotrophic soils, close to brown soils with partly marked podzolization process. This is usually a three-storey, sparse forest, with the canopy compactness rarely exceeding $70 \%$. The dominant tree is most often pedun-

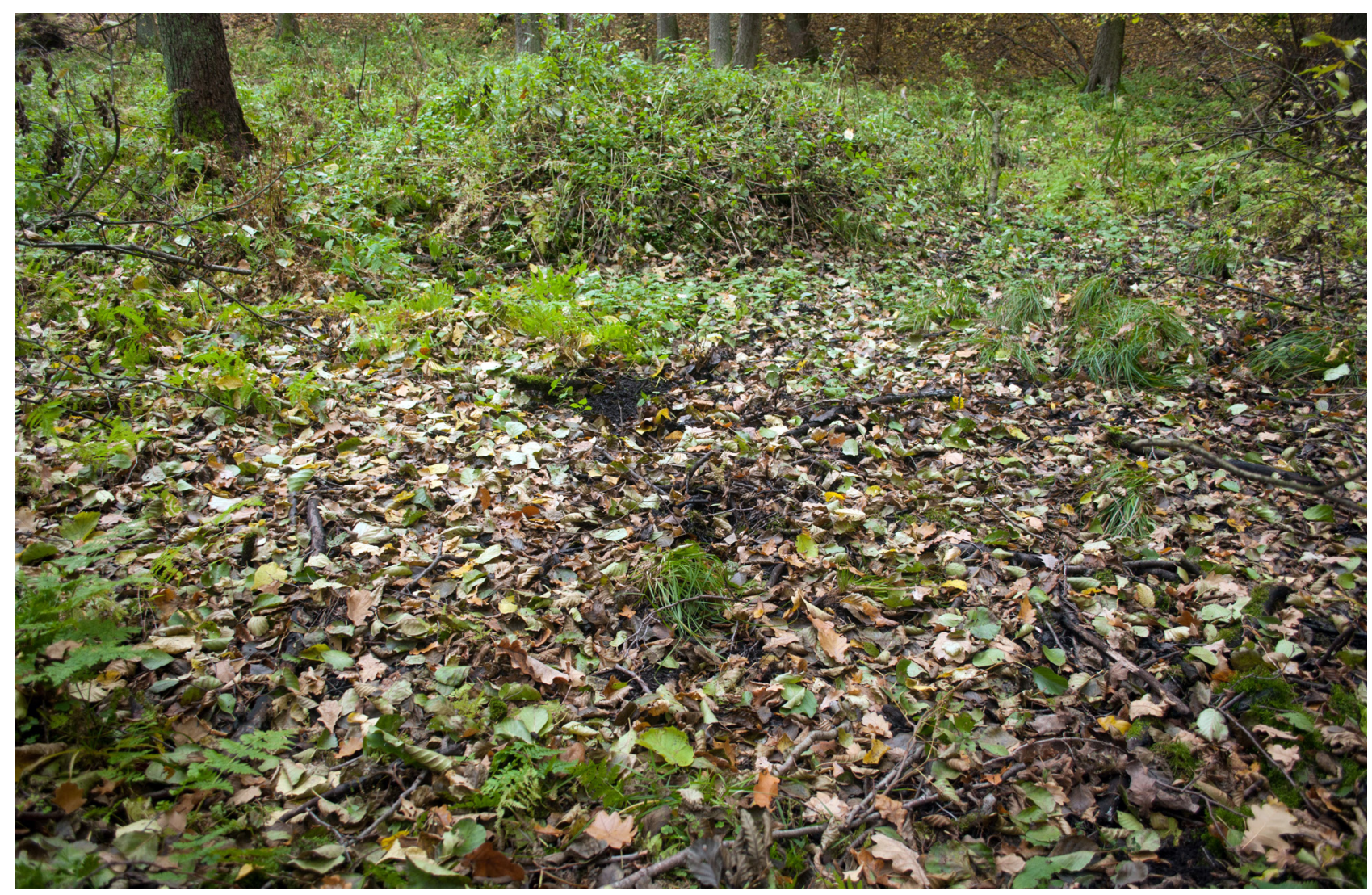

Fig. 9. Site 8, subcontinental oak-hornbeam forest. Photo: M. FRASUNKIEWICZ 
culate oak. The shrub layer is poor or lacking. The herb layer is rich but with a small cover, there is no moss layer (KĘPCZYŃSKI 1965). In the reserve the oak forest borders directly on riverine forests, hence the soil is very damp in places.

Site 5. Currant-alder carr (Ribeso nigri-Alnetum Sol.Górn. (1975) 1987). The forest (Fig. 6) grows in places where water stagnates most of the time so that the soil is not well aerated, slowing down decomposition of organic matter and forming peat beds. The dominant tree is black alder. The shrub layer is mainly composed of blackcurrant, alder buckthorn or rowan. The lichen-moss layer is usually poorly developed (MATUSZKIEWICZ 2008). The currant-alder carr occupies a relatively small part of the reserve; it develops mainly on the margins, in very damp fragments of the reserve (KĘPCZYŃSKI \& CYZMAN 1995).

Site 6. Ash-alder riverine forest (Fraxino-Alnetum W. Mat. 1952) (Fig. 7) is a damp habitat with constant movement of ground water but no major flooding episodes or longer periods of stagnation. The stands are composed of black alder and ash. The shrub layer is well-developed and includes bird cherry, hazel, and rowan. The moss and herb layer are poorly developed, with such species as Brachythecium rutabulum or Mnium undulatum (MATUSZKIEWICZ 2008). The ash-alder riverine forest grows in ground hollows, between the alder carr and slope parts of oak-hornbeam forest and on the boundary between the forest and cultivated fields (KĘPCZYŃSKI \& CYZMAN 1995).

Site 7. Subboreal mixed forest, Sarmatian variant (Serratulo-Pinetum (W. Mat. 1981) J. Mat. 1988). This variant of subboreal mixed forest (Fig. 8) grows in ground depressions where the ground water level is low. The soil is podzolic, originating from loose or poorly clayey sands. Strongly acidified rot occurs on its surface. Under the humic layer poorly clayey sand overlies loose sand. Precipitated iron compounds are marked in the loose sand level. Pine and spruce are the dominant trees (KĘPCZYŃSKI 1965).

Site 8. Subcontinental oak-hornbeam forest (TilioCarpinetum Tracz. 1962). The oak-hornbeam forest (Fig. 9) most often grows on fertile, damp soil (KĘPCZYŃSKI 1965). The main trees are hornbeam, pedunculate oak and linden, with some admixture of Norway maple or beech. The shrub layer is well-developed and composed of hazel, buckthorn, common and rough-stemmed spindle tree, bird cherry, fly honeysuckle, water elder, single-seed hawthorn and rowan. The lichen-moss layer is poor including, for example, Atrichum undulatum, Plagomnium affine or Eurhynchium angustirete (MATUSZKIEWICZ 2008).

\section{MATERIAL AND METHODS}

In each site gastropods were collected by eye in all available microhabitats (leaf-litter, vegetation, soil surface, tree trunks and logs at initial stages of decomposition) over an area of ca. $400 \mathrm{~m}^{2}$, during the time not shorter than two person-hours.

Herbs, grasses and sedges were shaken over a white tray. Live individuals were drowned in boiled, lukewarm water and then preserved in ethyl alcohol in case anatomical identification should become necessary. Besides, 151 litter and topsoil were sieved using a sieve of $1 \mathrm{~cm}$ mesh. The material was then dried, passed through a sieve of $2 \mathrm{~mm}$ mesh and hand-sorted under stereomicroscope. Only live specimens and identifiable fresh shells were used in the analysis.

The nomenclature and systematic arrangement follow MOLLUSCABASE (2019).
The completeness of collection was tested using the Chao index (CAMERON \& POKRYSZKO 2005). Between-site diversity was estimated using Whittaker's index $\left(\mathrm{I}_{\mathrm{w}}\right)$ and maximum Whittaker's index $\left(\mathrm{I}_{\text {MAX }}\right)$ (CAMERON \& POKRYSZKO 2005). Dominance and frequency were calculated according to DZIĘCZKOWSKI (1972). The similarity between the sites was assessed using the Nei estimator (POKRYSZKO \& CAMERON 2005). The fauna of the nature reserve was compared with those of seven other forest localities of different anthropogenic influence, all situated in the north-central half of the country and thus biogeographically similar i.e. potentially holding the same set of species. 


\section{RESULTS}

\section{COMPLETENESS OF INVENTORY}

The Chao index for individual sites (Table 2) ranged from 0.25 to 12.50 . Though the mean number of specimens per site was 347.7, in one site (7) it failed to meet the "ten or more times the number of species" criterion (CAMERON \& POKRYSZKO 2005). This apparent incompleteness seems not to result from inadequate collecting effort (see Discussion).

Table 2. Values of Chao index for individual sites

\begin{tabular}{lcccccccc}
\hline $\begin{array}{l}\text { Site } \\
\text { number }\end{array}$ & 1 & 2 & 3 & 4 & 5 & 6 & 7 & 8 \\
\hline $\begin{array}{l}\text { Chao } \\
\text { index } \\
\text { Mean }\end{array}$ & 4.50 & 2.25 & 2.00 & 2.25 & 4.50 & 12.50 & 0.25 & 1.00 \\
\hline
\end{tabular}

\section{SPECIES RICHNESS, COMPOSITION, STRUCTURE AND BETWEEN-SITE SIMILARITIES}

Thirty nine species were found in the studied area (Table 3): 27 species in the town of Skępe, and 30 in the nature reserve Stary Zagaj. Eighteen species were common for the town and the reserve, 9 occurred in the town only and 12 in the reserve only. The number of species per site was 8 to 21 (mean 13.88), the number of specimens 38 to 1,224 (mean $347.7)$. Four species $(10.26 \%)$ were forest-dwellers/ shade loving species. A great majority of species $(25 ; 64.10 \%)$ were euryoecious, the remainder were hygrophiles $(7 ; 17.95 \%)$ or xerothermophilous (3; $7.69 \%)$. Virtually all the species recorded were widely distributed (Holarctic, Palaearctic, Euro-Siberian, European in broad sense or species whose range includes all Poland). Limacus flavus and Limax maximus are introduced but still they occur all over the country, while Cepaea nemoralis is increasing its range eastward, in Poland reaching as far east as Rzeszów and Roztocze; C. hortensis inhabits the western half of the country (for ranges and habitat requirements see WIKTOR 2004).

With very few exceptions most species in most sites were characterised by very small dominance values, and in most of the sites the dominance structure was unbalanced (see e.g. sites 1-3 and 5-8 in Table 3 ), with one to three species constituting more than $50 \%$ of the malacocoenosis and the remaining ones represented by few or even single individuals. The dominance values varied from site to site: the main dominants were low-frequency species. The frequency ranged from 12.50 to $100 \%$, the only species with $100 \%$ frequency being Perpolita hammonis, and only 13 species showed frequencies $\geq 50 \%$, so the values may seem high but actually they result from the small number of sampling sites (species with single sites showed a $12.50 \%$ frequency and constituted $30.77 \%$ of all species; see Table 3). Whittaker's indices were: $\mathrm{I}_{\mathrm{W}} 2.81, \mathrm{I}_{\max } 1.86$, indicating a very high inter-site heterogeneity (see Discussion).

The most similar sites (Table 4; values given in bold) were 1 and 3, 1 and 4, 2 and 8, 4 and 6, 5 and 6,5 and 7,5 and 8,6 and 7,7 and 8 , thus the sites did not form any definite clusters, and the Nei values were generally small. The most dissimilar sites (underlined values in Table 4) were 1 and 7, 2 and 4, 2 and 7.

\section{SIMILARITY TO OTHER LOCALITIES IN THE NORTH-CENTRAL PART OF POLAND}

We compared the nature reserve Stary Zagaj (SZ in Tables 5 and 6) with seven other forest localities in Poland which were similar in terms of general habitat conditions and geographic location, and thus could be expected to hold originally similar faunas: Białowieża Forest (BF; CAMERON \& POKRYSZKO 2004), Romincka Forest (RF; MARZEC 2010), Wzniesienia Łódzkie Landscape Park (WŁ; SULIKOWSKA-DROZD 2011), nature reserves Grądy nad Moszczenicą (GM; SUliKOWSKA-DrozD 2010), Grądy nad Lindą (GL; SULIKOWSKA-DrOZD 2010), Lake Hańcza (LH; POKRYSZKO \& CAMERON 2006) and Kaszuby Upland (KU; CAMERON \& POKRYSZKO 2006). They differed, however, in the degree and duration of anthropogenic influence (age of tree stands, kind and degree of forest management, extent of forest fragmentation; see the references cited above). The species list for all these localities is given in Table 5 and the Nei values in Table 6.

The number of species in the compared localities ranges from 30 to 60 . Overall the list contains all the species that could be expected to occur in northern Poland. Even discounting species with only few or single isolated records in northern Poland (Helicigona lapicida, Faustina faustina, Isognomostoma isognomostomos), the species richness still varies very widely. None of the localities holds the whole set of species (67) which are biogeographically and ecologically available in the northern half of the country. With its 30 species, the nature reserve Stary Zagaj is the poorest among the four relatively poor localities (for species lists see Table 5), in contrast to the group of three rich (51-60 species) localities; one locality is moderately rich. Stary Zagaj and Lake Hańcza stand out in two respects: the complete absence of clausiliids ( 15 species recorded overall in all other localities) and the very small proportion of forest-dwellers (ca. $10 \%$ of forest-dwellers in Stary Zagaj and even less at Lake Hańcza). Other similarities include the dom- 


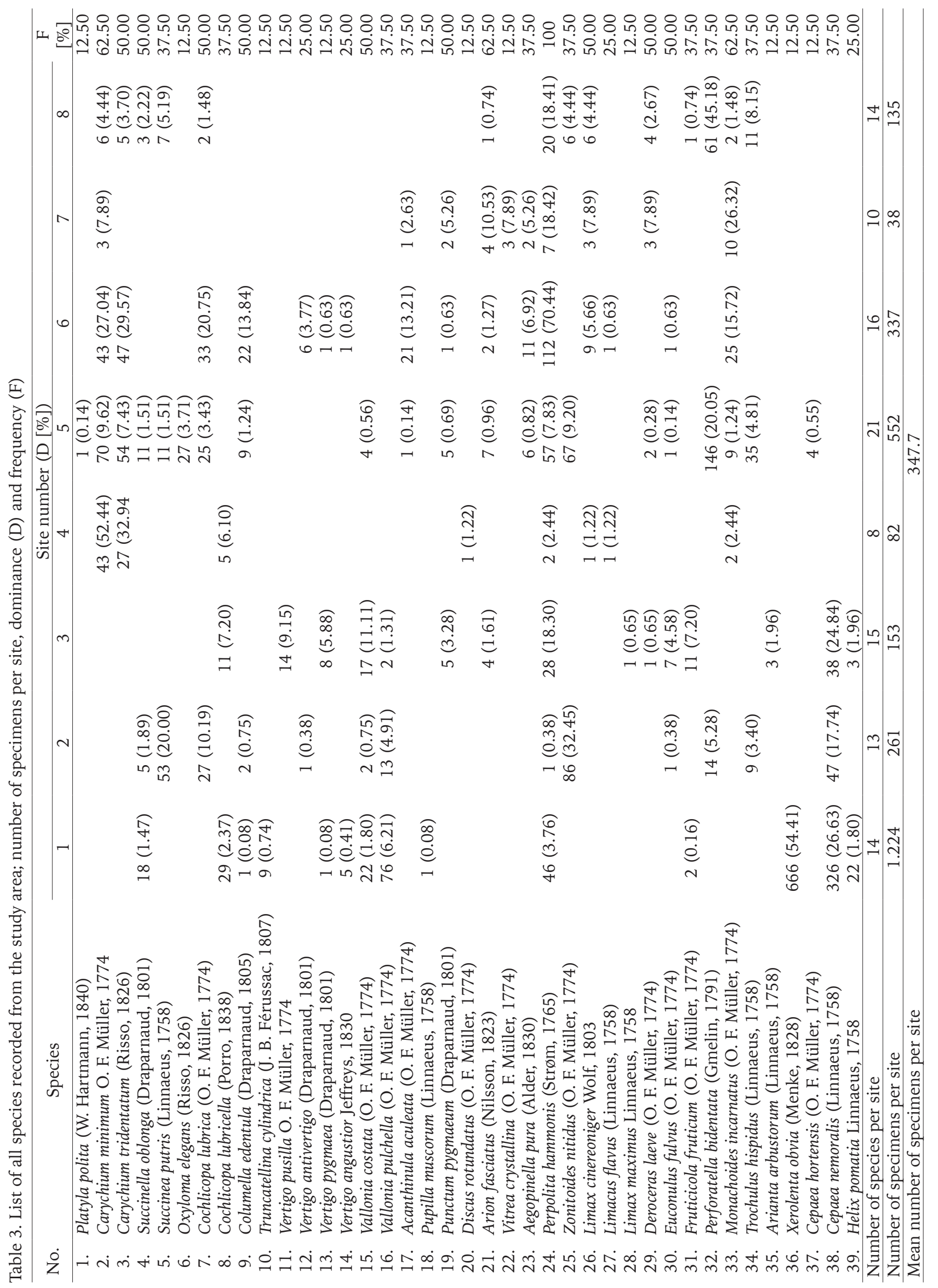


Table 4. Similarity between sampling sites expressed as Nei estimator; values exceeding 0.50 bolded, smallest values underlined

\begin{tabular}{ccccccccc}
\hline Locality & 1 & 2 & 3 & 4 & 5 & 6 & 7 & 8 \\
\hline 1 & $\times$ & 0.38 & 0.55 & 0.68 & 0.23 & 0.27 & $\underline{0.08}$ & 0.21 \\
2 & & $\times$ & 0.36 & $\underline{0.10}$ & 0.30 & 0.49 & $\underline{0.09}$ & $\mathbf{0 . 5 2}$ \\
3 & & & $\times$ & 0.18 & 0.39 & 0.32 & 0.33 & 0.28 \\
4 & & & & $\mathrm{X}$ & 0.31 & $\mathbf{0 . 5 3}$ & 0.45 & 0.47 \\
5 & & & & & $\times$ & 0.60 & 0.55 & 0.63 \\
6 & & & & & & $\times$ & 0.63 & 0.47 \\
7 & & & & & & & $\times$ & 0.51 \\
8 & & & & & & & & $\times$ \\
\hline
\end{tabular}

Table 6. Values of Nei estimator for eight forest localities (for symbols see text); values exceeding 0.70 bolded, smallest values underlined

\begin{tabular}{ccccccccc}
\hline & SZ & BF & RF & WŁ & GM & GL & LH & KU \\
\hline SZ & $\times$ & 0.55 & 0.51 & 0.54 & $\underline{0.41}$ & 0.55 & 0.60 & 0.55 \\
BF & & $\times$ & 0.75 & 0.60 & 0.56 & 0.62 & 0.65 & 0.66 \\
RF & & & $\times$ & 0.62 & 0.57 & 0.63 & 0.61 & 0.74 \\
WŁ & & & & $\times$ & 0.57 & 0.67 & 0.60 & 0.56 \\
GM & & & & & $\times$ & 0.75 & $\underline{0.46}$ & 0.61 \\
GL & & & & & & $\times$ & 0.50 & 0.55 \\
LH & & & & & & & $\times$ & 0.54 \\
KU & & & & & & & & $\times$ \\
\hline
\end{tabular}

Table 5. Species composition of the compared localities; for symbols see text. High-frequency species bolded, species with single records underlined

\begin{tabular}{|c|c|c|c|c|c|c|c|c|}
\hline Species & SZ & $\mathrm{BF}$ & RF & WŁ & GM & GL & LH & $\mathrm{KU}$ \\
\hline Platyla polita (W. Hartmann, 1840) & $\times$ & $\times$ & $\times$ & & $\times$ & $\times$ & & $x$ \\
\hline Carychium minimum O. F. Müller, 1774 & $x$ & $x$ & $\times$ & $\times$ & $x$ & $x$ & $\times$ & $x$ \\
\hline Carychium tridentatum (Risso, 1826) & $x$ & $x$ & $\times$ & $\times$ & $\times$ & $\times$ & $x$ & $\times$ \\
\hline Succinella oblonga (Draparnaud, 1801) & $\times$ & $\times$ & $\times$ & $\times$ & & & $\times$ & $x$ \\
\hline Succinea putris (Linnaeus, 1758) & $\times$ & $\times$ & $\times$ & $\times$ & $\times$ & $\times$ & $x$ & $\times$ \\
\hline Oxyloma elegans (Risso, 1826) & $\times$ & $\times$ & & $\times$ & & & & \\
\hline Oxyloma sarsii (Esmark, 1886) & & & & & & & $\times$ & \\
\hline Cochlicopa lubrica (O. F. Müller, 1774) & $\times$ & $\times$ & $\times$ & $\times$ & $\times$ & $x$ & $x$ & $\times$ \\
\hline Cochlicopa lubricella (Porro, 1838) & $\times$ & $x$ & $\times$ & $\times$ & & $\times$ & $x$ & $x$ \\
\hline Cochlicopa nitens (M. von Gallenstein, 1848) & & $\times$ & $\times$ & $\times$ & & & $\times$ & \\
\hline Columella aspera Waldén, 1966 & & & $\times$ & & & & & \\
\hline Columella edentula (Draparnaud, 1805) & $\times$ & $\times$ & $\times$ & $\times$ & & $\times$ & $\times$ & $\times$ \\
\hline Truncatellina cylindrica (J. B. Férussac, 1807) & & & & $\times$ & & & & \\
\hline Vertigo alpestris Alder, 1838 & & $\times$ & $\times$ & & $\times$ & & & $\times$ \\
\hline Vertigo antivertigo (Draparnaud, 1801) & $\times$ & & $\times$ & $\times$ & $x$ & & $\times$ & \\
\hline Vertigo pusilla O. F. Müller, 1774 & & $\times$ & $x$ & $x$ & $x$ & $\times$ & $x$ & $\times$ \\
\hline Vertigo pygmaea (Draparnaud, 1801) & $\times$ & & $\times$ & $\times$ & & & & \\
\hline Vertigo ronnebyensis (Westerlund, 1871) & & & $\times$ & & & & & \\
\hline Vertigo substriata (Jeffreys, 1833) & & $\times$ & $x$ & $\times$ & $\times$ & $\times$ & $x$ & $\times$ \\
\hline Vertigo angustior Jeffreys, 1830 & $\times$ & & & & & & & \\
\hline Pupilla muscorum (Linnaeus, 1758) & & & $\times$ & $\times$ & & & & \\
\hline Vallonia costata (O. F. Müller, 1774) & $\times$ & $\times$ & $\times$ & $\times$ & & & $\times$ & \\
\hline Vallonia pulchella (O. F. Müller, 1774) & & $\times$ & $\times$ & $\times$ & & & $x$ & \\
\hline Vallonia excentrica Sterki, 1893 & & & & $\times$ & & & & \\
\hline Acanthinula aculeata (O. F. Müller, 1774) & $\times$ & $\times$ & $\times$ & $\times$ & $\times$ & $\times$ & $x$ & $\times$ \\
\hline Merdigera obscura (O. F. Müller, 1774) & & & $\times$ & & & & & $x$ \\
\hline Punctum pygmaeum (Draparnaud, 1801) & $\times$ & $\times$ & $\times$ & $\times$ & $\times$ & $\times$ & $\times$ & $\times$ \\
\hline Discus ruderatus (W. Hartmann, 1821) & & $\times$ & $\times$ & & $\times$ & $\times$ & & \\
\hline Discus rotundatus (O. F. Müller, 1774) & $\times$ & $\times$ & $\times$ & $\times$ & $x$ & $x$ & $x$ & $\times$ \\
\hline Arion subfuscus (Draparnaud, 1805) & & $\times$ & $\times$ & $\times$ & $\times$ & $\times$ & $x$ & \\
\hline Arion fuscus (O. F. Müller, 1774) & & & & $\times$ & & & & \\
\hline Arion circumscriptus G. Johnston, 1828 & & & $\times$ & $x$ & $\times$ & $\times$ & $x$ & \\
\hline Arion fasciatus (Nilsson, 1823) & $\times$ & $\times$ & & & & & & \\
\hline Arion silvaticus Lohmander, 1937 & & & & $\times$ & & & & \\
\hline Arion vulgaris Moquin-Tandon, 1855 & & & & $x$ & & $\times$ & & \\
\hline Vitrina pellucida (O. F. Müller, 1774) & & $\times$ & $\times$ & $\times$ & $\times$ & $\times$ & $\times$ & $\times$ \\
\hline Vitrea contracta (Westerlund, 1871) & & & & & & & & $x$ \\
\hline
\end{tabular}


Table 5. continued

\begin{tabular}{|c|c|c|c|c|c|c|c|c|}
\hline Species & SZ & $\mathrm{BF}$ & RF & WŁ & GM & GL & $\mathrm{LH}$ & $\mathrm{KU}$ \\
\hline Vitrea crystallina (O. F. Müller, 1774) & $\times$ & $\times$ & $\times$ & $\times$ & $\times$ & $\times$ & $\times$ & $\times$ \\
\hline Aegopinella minor (Stabile, 1864) & & $x$ & $x$ & & & & $\times$ & \\
\hline Aegopinella nitidula (Draparnaud, 1805) & & & & & & & & $x$ \\
\hline Aegopinella pura (Alder, 1830) & $\times$ & $\times$ & $\times$ & $\times$ & $\times$ & $\times$ & $\times$ & $x$ \\
\hline Perpolita hammonis (Strøm, 1765) & $\times$ & $\times$ & $\times$ & $\times$ & $x$ & $x$ & $\times$ & $x$ \\
\hline Perpolita petronella (L. Pfeiffer, 1853) & & $\times$ & $\times$ & $\times$ & $x$ & $\times$ & $\times$ & $x$ \\
\hline Oxychilus cellarius (O. F. Müller, 1774) & & & & & & & & $x$ \\
\hline Oxychilus draparnaudi (H. Beck, 1837) & & & & $\times$ & & & & \\
\hline Oxychilus alliarius (J. S. Miller, 1822) & & & $\times$ & $\times$ & $x$ & $x$ & & $x$ \\
\hline Zonitoides nitidus (O. F. Müller, 1774) & $\times$ & $\times$ & $\times$ & $\times$ & $\times$ & $\times$ & $\times$ & \\
\hline Limax cinereoniger Wolf, 1803 & $\times$ & $\times$ & $\times$ & $\times$ & $x$ & $x$ & & \\
\hline Limax maximus Linnaeus, 1758 & & & & $\times$ & & & & \\
\hline Limacus flavus (Linnaeus, 1758) & $\times$ & & & & & & & \\
\hline Malacolimax tenellus (O. F. Müller, 1774) & & $\times$ & $\times$ & $\times$ & $\times$ & $\times$ & $x$ & \\
\hline Lehmannia marginata (O. F. Müller, 1774) & & & $\times$ & $\times$ & & & & \\
\hline Ambigolimax nyctelius (Bourguignat, 1861) & & $\times$ & & & & & & \\
\hline Deroceras agreste (Linnaeus, 1758) & & & & $\times$ & & & & \\
\hline Deroceras laeve (O. F. Müller, 1774) & $\times$ & $\times$ & & $\times$ & $\times$ & $\times$ & $\times$ & \\
\hline Deroceras reticulatum (O. F. Müller, 1774) & & & & $\times$ & & & & \\
\hline Euconulus alderi (Gray, 1840) & & & $\times$ & $\times$ & & & & \\
\hline Euconulus fulvus (O. F. Müller, 1774) & $\times$ & $\times$ & $\times$ & $\times$ & $\times$ & $\times$ & $x$ & $x$ \\
\hline Cochlodina laminata (Montagu, 1803) & & $x$ & $\times$ & & & & & $x$ \\
\hline Cochlodina orthostoma (Menke, 1828) & & $\times$ & $\times$ & & & & & $x$ \\
\hline Ruthenica filograna (Rossmässler, 1836) & & $\times$ & $\times$ & & $\times$ & $x$ & & $x$ \\
\hline Macrogastra borealis bielzi H. Nordsieck, 1993 & & & $\times$ & & & & & $x$ \\
\hline Macrogastra plicatula (Draparnaud, 1801) & & $\times$ & $\times$ & & & & & $x$ \\
\hline Macrogastra tumida (Rossmässler, 1836) & & $\times$ & $\times$ & & & & & \\
\hline Macrogastra ventricosa (Draparnaud, 1801) & & $\times$ & $\times$ & & & & & $x$ \\
\hline Clausilia bidentata (Strøm, 1765) & & $\times$ & $\times$ & & & & & $x$ \\
\hline Clausilia cruciata (S. Studer, 1820) & & & $\times$ & & $\times$ & & & \\
\hline Clausilia dubia Draparnaud, 1805 & & $\times$ & $\times$ & & & & & \\
\hline Clausilia pumila (C. Pfeiffer, 1828) & & $\times$ & $\times$ & & & & & $x$ \\
\hline Laciniaria plicata (Draparnaud, 1801) & & $\times$ & $\times$ & & & & & $x$ \\
\hline Alinda biplicata (Montagu, 1803) & & & & & $\times$ & & & $x$ \\
\hline Strigillaria cana (Held, 1836) & & $\times$ & $\times$ & & & & & \\
\hline Fruticicola fruticum (O. F. Müller, 1774) & & $\times$ & $\times$ & & $\times$ & & & $x$ \\
\hline Perforatella bidentata (Gmelin, 1791) & $\times$ & $\times$ & $\times$ & $\times$ & $\times$ & $\times$ & $\times$ & $\times$ \\
\hline Monachoides incarnatus (O. F. Müller, 1774) & $x$ & & & $\times$ & $x$ & $\times$ & & \\
\hline Monachoides vicinus (Rossmässler, 1842) & & $\times$ & & & & & & \\
\hline Pseudotrichia rubiginosa (Rossmässler, 1838) & & $x$ & & $\times$ & $\times$ & & & \\
\hline Trochulus hispidus (Linnaeus, 1758) & $\times$ & $\times$ & $\times$ & $\times$ & & & & $x$ \\
\hline Euomphalia strigella (Draparnaud, 1801) & & & $\times$ & & & & $\times$ & $x$ \\
\hline Arianta arbustorum (Linnaeus, 1758) & $\times$ & & $\times$ & $\times$ & & & $\times$ & $x$ \\
\hline Helicigona lapicida (Linnaeus, 1758) & & & $\times$ & & & & & $x$ \\
\hline Faustina faustina (Rossmässler, 1835) & & & $x$ & & & & & \\
\hline Isognomostoma isognomostomos (Schröter, 1784) & & $\times$ & & & & & & \\
\hline Cepaea hortensis (O. F. Müller, 1774) & $\times$ & $\times$ & $\times$ & $\times$ & & & $x$ & $x$ \\
\hline Cepaea nemoralis (Linnaeus, 1758) & & & & $\times$ & & $\times$ & & \\
\hline Helix pomatia Linnaeus, 1758 & & $\times$ & & $\times$ & $\times$ & & & $\times$ \\
\hline Total species & 30 & 52 & 60 & 51 & 34 & 31 & 33 & 43 \\
\hline
\end{tabular}


inance structure, with a group of one to three dominant species, the complete absence of tree-climbing species, and the small abundance and frequency of Discus rotundatus - a species closely associated with rotting timber (KUŹNIK-KOWALSKA 1999).

\section{DISCUSSION}

Considering the values of the Chao index, the set from Stary Zagaj seems to be only partly complete. However, this may reflect the genuine poverty of the fauna, in terms of both population density and species richness. Unlike the other areas (CAMERON \& POKRYSZKO 2004, 2006, POKRYSZKO \& CAMERON 2006, MARZEC 2010, SULIKOWSKA-DROZD 2010, 2011) the samples were taken in three different seasons, on each occasion with two methods (searching the microhabitats and sieving), to avoid sampling errors resulting from the short life cycles and the weather-dependent reproduction of some species (for life history details see WHITNEY 1938, MORTON 1954, UMIŃSKI 1975, BAUR 1989, BULMAN 1990, POKRYSZKO 1990, KUŹNIK-KOWALSKA \& PROĆKÓW 2016).

The small proportion of forest-dwellers, the lack of clausiliids and the near-absence of tree-climbing and timber-dependent species appear to be symptomatic of habitat disturbance. In this case the small abundance may result from unfavourable conditions (poor soils, age of tree stands), and the low frequencies from heterogeneity of the sites which in turn reflects a genuine patchy distribution. The values of Whittaker's index are high $\left(\mathrm{I}_{\mathrm{W}} 2.81, \mathrm{I}_{\text {MAX }} 1.86\right)$ and thus not only much higher than at Lake Hańcza (1.6), but also much higher than those for similar clusters of sites considered across N. Europe, where the value of $\mathrm{I}_{\mathrm{MAX}}$ of 1.43 is at the high end of the range (POKRYSZKO \& CAMERON 2005).

There is no unequivocal published evidence that the nature reserve Stary Zagaj was part of an extensive forest complex in the past. At present forests cover ca. $20 \%$ of the region and pine stands prevail while mixed or deciduous forests are limited to small stands growing on slightly richer soil (KĘPCZYŃSKI \& CYZMAN 1995, KOPLIŃSKI et al. 2010). It is likely that in the past the forest was continuous. The area started being increasingly densely populated in the 14th and 15th c. when large parts of the forest were felled for building, fuel and to gain arable land (KĘPCZYŃSKI \& CYZMAN 1995); human habitations were mainly built on rivers and lakes where the soil was richer. Now, in the Skępe municipality, arable land constitutes ca. 51\% (KOPLIŃSKI et al. 2010). The second stage of reduction of the forest-covered areas took place during industrial development in the 16th c. (charcoal, tar, glass and iron production) and in-
The mean Nei value for Stary Zagaj vs. all other localities is small (0.53), the locality is the least similar to Grądy nad Moszczenicą (0.41), and the most similar to Lake Hańcza (Table 6).

creasing colonisation in the 17th, 18th and early 19th c. (KĘPCZYŃSKI \& CYZMAN 1995), followed by intensive management of the remaining forest fragments (Stary Zagaj obtained the status of nature reserve in 2011, and though it has been nominally strictly protected since 2017 it is still managed!). This (sanitary cuts, removal of dead timber implying herb layer and leaf-litter damage), combined with the forest fragmentation and originally rather poor soils, are probably the reasons for the impoverishment of the fauna. The fauna of Lake Hańcza is similarly depauperate (POKRYSZKO \& CAMERON 2006).

In spite of the fact that each of the compared localities was represented by a different number of sites, their species richness shows differences which reflect the general tendency. The number of species in the rich localities (Białowieża Forest, Romincka Forest, Kaszuby Upland), though they are not very similar (see Table 6), is comparable with such numbers in very rich localities in the Carpathians (up to 57 species; SZYBIAK 2000). They are also much less varied; while $\mathrm{I}_{\mathrm{MAX}}$ is $1.3-1.5$ for the richest localities in the Carpathians (POKRYSZKO \& CAMERON 2005), it ranges from 1.4 in Białowieża (CAMERON \& POKRYSZKO 2004) to 1.5-1.7 in Romincka Forest (MARZEC 2010). On the other hand, the group of four poor localities in Table 5 has much fewer species, unbalanced dominance structure and in two cases clausiliids are absent. Besides, the three poor localities are less similar to each other (Nei 0.41-0.60) than are the four rich localities (Nei 0.66-0.75). The small similarity in the group of poor localities suggests that the depauperation of their faunas was to a large extent random: different species were deleted from each locality which before their impoverishment may have held a much larger fauna, more similar to that of Białowieża and Romincka Forest.

Assuming an adequate collecting effort, the unbalanced dominance structure, small between-site similarity reflected also by the high values of Whittaker's index, small proportion of forest-dwellers combined with the near-absence or absence of clausiliids and other tree-climbing and/or timber-dependent species, seem to be crucial symptoms of anthropogenic changes in effect at present or in the past.

Though Stary Zagaj offers habitat conditions which are far from optimum, surprisingly Vertigo angustior was found in the nature reserve (site 6: 
ash-alder riverine forest). Besides, it was found in the town of Skępe, in site 1 (railway embankment). It is listed in Annex II to the EU Habitats Directive (EEC 1992) and in the IUCN Red List of Threatened Species (IUCN 2014). Though in the EU it is regarded as threatened (MOORKENS et al. 2012), the number of its records is increasing. The current number of such records from Poland is 93 (KSIĄŻKIEWICZ et

\section{REFERENCES}

BAUR B. 1989. Growth and reproduction in the minute land snail Punctum pygmaeum (Draparnaud). Journal of Molluscan Studies 55: 383-387. https://doi. org/10.1093/mollus/55.3.383

BULMAN K. 1990. Life history of Carychium tridentatum (Risso, 1826) (Gastropoda: Pulmonata: Ellobiidae) in the laboratory. Journal of Conchology 33: 321-333.

CAmeron R. A. D., PokryszKo B. M. 2004. Land mollusc faunas of Białowieża forest (Poland), and the character and survival of forest faunas in the North European Plain. Journal of Molluscan Studies 70: 149-164. https://doi.org/10.1093/mollus/70.2.149

CAmeron R. A. D., POKRYszKo B. M. 2005. Estimating the species richness and composition of land mollusc communities: problems, consequences and practical advice. Journal of Conchology 38: 529-547.

CAmeron R. A. D., Pokryszko B. M. 2006. Forest snail fauna in the Kaszuby Uplands (Pomerania): a rich northern refuge. Folia Malacologica 14: 75-82. https:// doi.org/10.12657/folmal.014.012

Cameron R. A. D., Pokryszko B. M., Horsák M. 2010. Land snail faunas in Polish forests: patterns of richness and composition in a post-glacial landscape. Malacologia 53: 77-134. https://doi.org/10.4002/040.053.0105

CAMERon R. A. D., POKRYSZKo B. M., HorsáK M. SIRBU I., GHEOCA V. 2011. Forest snail faunas from Transylvania (Romania) and their relationship to the faunas of Central and Northern Europe. Biological Journal of the Linnean Society 102: 471-479. https:// doi.org/10.1111/j.1095-8312.2011.01730.x

DROzDOWSKI A. 1980. Ślimaki (Gastropoda) obszaru kujawsko-pomorskiego. Acta Universitatis Nicolai Copernici, Nauki Matematyczno-Przyrodnicze, Biologia 23: 25-36.

DROZDOWSKI A. 1997. Uwagi o ślimakach wymarłych i ginących na obszarze kujawsko-pomorskim. Acta Universitatis Nicolai Copernici, Nauki MatematycznoPrzyrodnicze, Biologia 53: 3-7.

DYDUCH A. 1980. Ślimaki lądowe (Gastropoda terrestria) wybranych zbiorowisk roślinnych Puszczy Białowieskiej i Puszczy Niepołomickiej. Ochrona Przyrody 43: 223272.

DZIĘCZKOwSKI A. 1972. Badania ilościowe ślimaków buczyn południowo-zachodniej Polski. Studium ekologiczno-faunistyczne. Prace Komisji Biologicznej PTPN 35: 243-332. al. 2015, POKRYSZKO et al. 2016), nevertheless the new records are noteworthy.

\section{ACKNOWLEDGEMENTS}

We thank two anonymous reviewers for their helpful comments.

EEC 1992. Council directive on the conservation of natural habitats and of wild fauna and flora (The habitats and species directive), Annex II, 92/43/EEC. Official Journal of the European Communities No L 206/7, Brussels Council Directive.

HoRsÁK M., HÁJEK M. 2005. Habitat requirements and distribution of Vertigo geyeri (Gastropoda: Pulmonata) in Western Carpathian rich fens. Journal of Conchology 38: 683-700.

IUCN 2014. The IUCN Red List of Threatened Species. Version 2014.2. Available online at http://www.iucnredlist.org (accessed 14 October 2019).

KĘPCZYŃSKI K. 1960. Zespoły roślinne Jezior Skępskich i otaczających je łąk. Studia Societatis Scientiarum Torunensis 6: 1-244.

KĘPCZYŃSKI K. 1965. Szata roślinna Wysoczyzny Dobrzyńskiej. Wydawnictwo Uniwersytetu Mikołaja Kopernika, Toruń.

KĘPCZYŃSKI K., CYZMAN W. 1995. Szata roślinna projektowanego rezerwatu „Stary Zagaj” koło Skępego. Acta Universitatis Nicolai Copernici, Nauki MatematycznoPrzyrodnicze, Biologia 48: 93-136.

KOPLIŃSKI M., SZluBOWSKI K., SMÓ£KA M., DŁUgOSZ S. 2010. Miasto i gmina Skępe. Studium uwarunkowań i kierunków zagospodarowania przestrzennego. Część A. Available online at https://skepe.bip.net.pl/?a=1229 (accessed 14 October 2019).

KSIĄŻKIEWICZ Z., BIEREŻNOJ-BAZILLE U., KRAJEWSKI Ł., GOŁDYN B. 2015. New records of Vertigo geyeri Lindholm, 1925, V. moulinsiana (Dupuy, 1849) and V. angustior Jeffreys, 1830 (Gastropoda: Pulmonata: Vertiginidae) in Poland. Folia Malacologica 23: 121-136. https://doi. org/10.12657/folmal.023.006

KUŹNIK-KOWALSKA E. 1999. Life cycle and population dynamics of Discus rotundatus (O. F. Müller, 1774) (Gastropoda: Pulmonata: Endodontidae). Folia Malacologica 7: 5-17. https://doi.org/10.12657/folmal.007.001

KuŹNIK-KowAlSKA E., ProćKÓW M. 2016. Reproductive biology and growth of two Vallonia species in laboratory conditions (Gastropoda: Eupulmonata: Valloniidae). Folia Malacologica 24: 265-273. https:// doi.org/10.12657/folmal.024.022

MARZEC M. 2010. Romincka Forest - a malacofauna refuge of European significance. Folia Malacologica 18: 71-82. https://doi.org/10.2478/v10125-010-0006-z 
MAtUSZKIEWICZ J. M. 2008. Zespoły leśne Polski. PWN, Warszawa.

MOLlUSCABASE 2019. Available online at www.molluscabase.org (accessed 14 October 2019).

MoORKENS E., KILLEEN I., SEDDON M. 2012. Vertigo angustior. The IUCN Red List of Threatened Species 2012: e.T22935A16658012.

MORTON J. E. 1954. Notes on the ecology and annual cycle of Carychium tridentatum at Box Hill. Proceedings of the Malacological Society of London 31: 30-46. https://doi org/10.1093/oxfordjournals.mollus.a064723

NOWAK L., STAŃCZAK J., ZNAJEWSKA A. 2013. Ludność. Stan i struktura w przekroju terytorialnym (Stan w dniu 30 VI 2013 r.). Główny Urząd Statystyczny, Warszawa. Available online at www.stat.gov.pl (accessed 30 September 2018).

PIECHOCKI A. 1981. Współczesne i subfosylne mięczaki (Mollusca) Gór Świętokrzyskich. Habilitation Thesis, Acta Universitatis Lodziensis, Łódź.

PIEŃKOWSKA J. R., ProćKÓw M., GÓRKA M., LEsICKI A. 2018. Distribution of Monacha claustralis (Rossmässler, 1834) and M. cartusiana (O. F. Müller, 1774) (Eupulmonata: Hygromiidae) in Central European and Balkan countries: new data. Folia Malacologica 26: 103-120. https://doi.org/10.12657/folmal.026.009

POKRYSZKO B. M. 1990. Life history and population dynamics of Vertigo pusilla O. F. Müller (Gastropoda: Pulmonata: Vertiginidae), with some notes on shell and genital variability. Annales Zoologici 43: 407-432.

PokryszKo B. M., CAMERON R. A. D. 2005. Geographical variation in the composition and richness of forest snail faunas in northern Europe. Records of the Western Australian Museum, Supplement 68: 115-132. https:// doi.org/10.18195/issn.0313-122x.68.2005.115-132

POKRYSZKO B. M., CAMERON R. A. D. 2006. Land snail communities at Lake Hańcza (NE. Poland). Folia Malacologica 14: 63-69.

POKRYSZKO B. M., RUTA R., KSIĄŻKIEWICZ-PARULSKA Z. 2016. The first record of Vertigo geyeri Lindholm, 1925 (Gastropoda: Pulmonata: Vertiginidae) in NorthWestern Poland. Folia Malacologica 24: 63-68. https:// doi.org/10.12657/folmal.024.009

RAPORT 2018. Raport o stanie Miasta i Gminy Skępe za rok 2018. Available online at http://bip.skepe.pl/?c=597 (accessed 16 October 2019).
RAKOWSKI G., WÓJCIK J., WALCZAK M., SMOGORZEWSKA M., BRodOWSKA M. 2005. Rezerwaty przyrody w Polsce Północnej. Instytut Ochrony Środowiska, Warszawa.

RĄKOWSKI G., WALCZAK M., SMOGORZEWSKA M. 2012. Obszary Natura 2000 w Polsce II. Specjalne obszary ochrony siedlisk w Polsce Północnej. Instytut Ochrony Środowiska - Państwowy Instytut Badawczy, Warszawa.

RIEDEL A. 1988. Ślimaki lądowe. Gastropoda terrestria. Katalog Fauny Polski 46. PWN, Warszawa.

SCHENKOVÁ V., HorsáK M., PlesKovÁ Z., PAWLIKOWSKI P. 2012. Habitat preferences and conservation of Vertigo geyeri (Gastropoda: Pulmonata) in Slovakia and Poland. Journal of Molluscan Studies 78: 105-111. https://doi. org/10.1093/mollus/eyr046

SULIKOWSKA-DROZD A. 2010. Nature reserves Grądy nad Moszczenicą and Grądy nad Lindą - refuges of forest malacofauna in central Poland. Folia Malacologica 18: 59-69. https://doi.org/10.2478/v10125-010-0005-0

SULIKOWSKA-DROZD A. 2011. Ślimaki lądowe Parku Krajobrazowego Wzniesień Łódzkich. Chrońmy Przyrodę Ojczystą 67: 244-253.

SZYBIAK K. 2000. Malacocenoses of the valley of the stream Pieniński Potok, Pieniny National Park. Folia Malacologica 8: 249-256. https://doi.org/10.12657/ folmal.008.021

UMIŃSKI T. 1975. Vitrinidae (Mollusca, Gastropoda) of Poland. Their density and related problems. Annales Zoologici 33: 17-33.

WHITNEY M. E. 1938. Some observations on the reproductive cycle of a common land snail, Vallonia pulchella, influence of environmental factors. Proceedings of the Indiana Academy of Science 47: 299-307.

WikTOR A. 2004. Ślimaki lądowe Polski. Mantis, Olsztyn.

ZAJAC K., KSIĄŻKIEWICZZ., LIPIŃSKA A. 2012. Poczwarówka Geyera Vertigo geyeri Lindholm, 1925. In: MAKOMASKAJUCHIEWICZ M., BARAN P. (eds). Monitoring gatunków zwierząt. Przewodnik monitoringu. Część II. GIOŚ, Warszawa, pp. 447-462.

Received: February 29th, 2020

Revised: May 5th, 2020

Accepted: May 25th, 2020

Published on-line: June 1st, 2020 